Social Work \& Education

(C) SW\&E, 2019

УДК 378.147.091.033-027.22:004]:364-78

DOI: $10.25128 / 2520-6230.19 .1 .10$
Дударьов, В. \& Щербина, С. (2019). Особливості інтерактивних технологій навчання у професійній підготовці соціального працівника, Social Work and Education, Vol. 6, No. 1., pp. 94-105. DOI: $10.25128 / 2520-6230.19 .1 .10$

\section{ОСОБЛИВОСТІ} ІНТЕРАКТИВНИХ ТЕХНОЛОГІЙ
НАВЧАННЯ У ПРОФЕСІЙНІЙ
ПІДГОТОВЦІ СОЦІАЛЬНОГО
ПРАЦІВНИКА
Віталій Дударьов, кандидат політичних наук, доиент кафедри соиіальної роботи

Національний університет «Запорізька політехніка», м. Запоріжжя, Украӥна kafedra_sr@zntu.edu.ua

ORCID: 0000-0002-0535-4014

\section{Сергій Щербина,} кандидат соиіологічних наук, дочент кафедри соиіальної роботи, Національний університет «Запорізька політехніка», м. Запоріжжя, Україна sergshcherbina70@gmail.com

ORCID: 0000-0002-9211-1773

Article history:

Received: January 12, 2018

1st Revision: Febuary 22, 2019

Accepted: March 30, 2019
АНОТАЦІЯ. Організація інтерактивного навчання передбачає моделювання життєвих ситуацій, використання рольових ігор, спільне розв'язання проблем. Воно ефективно сприяє формуванню цінностей, навичок i вмінь, створенню атмосфери співпраці, взаємодії, дає змогу соціальному працівнику набути професійно важливих якостей в сфері надання соціальних послуг. Розглянуто структурнопроцесуальні характеристики інтерактивних технологій i ïх основні форми: case-study, навчальний тренінг, ігрові методи.

3 орієнтації на особистісні структури інтерактивні технології навчання $€$ інформаційно-операційними, оскільки вони сприяють формуванню знань, умінь і навичок 3 предметів, а також способів розумових дій.

Ключові слова: навчання; інтерактивні технології; соціальний працівник; case-study; навчальний тренінг; ігрові методи. 


\section{Вступ}

В сучасній Україні створюються умови для переходу до гуманітарного, особистісно-орієнтованого, спрямованого на формування духовно багатої особистості, 3 можливостями розкриття потенційних здібностей кожної людини. Одними з основних інновацій у галузі освіти є інтерактивні технології навчання.

Впровадження інтерактивних виховних технологій у свою діяльність повинно стосуватись також і соціальних працівників та соціальних педагогів. Адже це фахівці, які в організації своєї роботи надають пріоритет створенню здорового мікроклімату в колективі, гуманізації міжособистісних відносин, сприяють реалізації здібностей кожного учня, захисту його інтересів, організації дозвілля, включенню в соціальну корисну діяльність та інше.

Соціальний працівник повинен вміти знаходити, створювати та активно застосовувати сучасні інтерактивні вправи, методики, завдання. Сприяти залученню дитини до вирішення проблем шляхом тренінгів, театральних вистав, флеш-мобів. В цьому аспекті соціальний працівник повинен сам набути досвіду навчання за інтерактивними технологіями, тому особливого значення набуває виявлення особливостей основних форм інтерактивного навчання в системі професійної підготовки соціальних працівників з позиції їх структурно-функціонального аналізу.

Використання інтерактивних технологій представлені в роботах: В. Беспалько, В. Свдокимова, М. Кларіна, Е. Пєхоти, Г. Селевко, В. Серікова, С. Сисоєвої, I. Якиманскої; теоретичні й практичні аспекти в наукових працях Е. Пєхоти, Є. Пометун, Л. Пироженко, А. Панченкова, Т. Ремех, О. Саган, О. Стребной та інших вітчизняних і зарубіжних учених. Інтерактивні технології навчання, як технології, що сприяють соціальному становленню особистості, розглянуті в роботах Б. Ананьєва, Л. Виготського та ін. Проблемам інтерактивного спілкування присвячені наукові праці М. Богомолової, Б. Ломова, Р. Немова, Л. Петровської, Л. Уманського та ін.

Мета статті. Визначити особливості інтерактивних технологій навчання в сучасній системі професійної підготовки соціальних працівників.

В основу методології дослідження покладені загальнотеоретичні й спеціальні методи наукового пізнання, принципи і підходи щодо визначення сутності інтерактивного навчання в сучасному навчальному процесі, аналіз використання інтерактивних технологій та здатність їх сприяти формуванню навичок міжособистісного спілкування, розвитку комунікативних здібностей, виробленню навичок роботи в малих групах, формуванню умінь самостійного мислення, отримання практичного досвіду діяльності у різних ситуаціях.

\section{Основна частина}

Якщо скористатися класифікацією, запропонованою Е. Голантом у 60-х роках XX ст., то всі типи і методи навчання можна поділити на активні та пасивні. У своїй класифікації А. Гриненко використовує «пасивність» як визначення низького рівня активності суб'єктів навчання, переважно репродуктивної діяльності за майже цілковитої відсутності самостійності й творчості (Гриненко, 2003). До цієї класифікації О. Пометун і Л. Пироженко додають інтерактивне навчання як різновид активного, котрий, однак, має свої закономірності та особливості (Архипова, 2002). Сутність інтерактивного навчання полягає в тому, що навчальний процес відбувається за умов постійної, активної взаємодії всіх учнів. Це співнавчання, взаємонавчання (колективне, групове, навчання в співпраці), де учень і вчитель $\epsilon$ рівноправними, рівнозначними суб'єктами навчання. Педагог виступає в ролі організатора процесу навчання, лідера групи. Організація інтерактивного навчання передбачає моделювання життєвих ситуацій, використання рольових ігор, спільне 
розв'язання проблем. Воно ефективно сприяє формуванню цінностей, навичок i вмінь, створенню атмосфери співпраці, взаємодіі, дає змогу педагогу стати справжнім лідером дитячого колективу (Біда, 2007, с.7). Розробку елементів інтерактивного навчання ми можемо знайти в працях В.Сухомлинського, творчості вчителів-новаторів 70-80-х рp. (Ш. Амонашвілі, В. Шаталова, С. Ільїна, С. Лисенкової), теорії розвивального навчання.

Проблема навчального спіробітництва активно і всебічно розробляється в останні десятиліття в нашій країні і за рубежем (Т. Коннікова, А. Мудрик, В. Ядов, Д. Фельдштейн, Б. Кричевський).

Сучасна освіта - це освіта для людини. Її стрижнем $є$ розвиваюча, культуротворча, домінанта, виховання здатності до самоосвіти і саморозвитку особистості, яка вміє використовувати набуті знання i вміння для творчого розв'язання проблем, критично мислити, опрацьовувати різноманітну інформацію, прагне змінити своє життя (Нойфельд, 1993, с.68).

Застосування інтерактивних технологій висуває певні вимоги до структури уроків. Як правило, структура таких занять складається 3 п'яти елементів: 1) мотивація; 2) оголошення, представлення теми та очікуваних навчальних результатів; 3) надання необхідної інформації; 4) інтерактивна вправа - центральна частина заняття; 5) підбиття підсумків, оцінювання результатів уроку.

Під час проведення уроків застосовують парну і групову роботу (в малих та великих групах). Це спонукає учнів висловлювати свої думки, формує вміння переконувати, вести дискусію. 3 метою підвищення ефективності уроку як основної форми навчання проводять уроки-лекції, уроки-семінари, комбіновані уроки, уроки-заліки, уроки-консультації, використовуючи різні сучасні технології (Павелків, 2013, с.123).

Термін «інтерактивне навчання» почав використовуватись 3 кінця 90-х років XX ст. i, на думку науковців, має такі класифікаційні ознаки: з точки зору філософіїце діалектичний процес; за орієнтацією на особистісні структури його можна охарактеризувати як інформаційне й операційне одночасно; за характером змісту загальноосвітне, соціально-психолого-педагогічне, культуротворче; за механізмом засвоєння - як асоціативно-рефлекторне; за основним чинником розвитку - як соціогенне; за підходом до особистості - як антропоцентричне; за переважаючими методами - як проблемно-діалогічне, пояснювально-ілюстративне; за кооперацією учасників - як групове, парне, фронтальне, індивідуальне; за організаційними формами - як альтернативне традиційному класно-урочному, як інноваційне, за умов якого заняття проводяться в активній формі проблемної лекції, семінару, брейнстормінгу, психодрами, диспуту, дебатів, діалогу, полілогу, прес-конференції, ділових і дидактичних ігор, інсценування, тренінгів тощо (загалом у діловій та освітній сфері сьогодні використовується більше 2000 видів інтеракціiі) .

Процес навчання - не автоматичне вкладання навчального матеріалу в голову учня. Адже куди важливіше навчити, ніж просто розповісти. Цей процес потребує напруженої розумової роботи підлітка та його власної активної участі в цьому процесі. Цю мету і переслідує застосування інтерактивних технологій.

Інтерактивні технології - це порівняно новий, творчий, цікавий підхід до організації навчальної діяльності учнів. Творчість використовувалась в практичній соціальні роботі від самого початку існування професії, саме творчість дає можливість соціальним працівникам рухатися вперед в своій професійній діяльності (Huss, E. \& Sela-Amit, M., 2018).

Слово «інтерактив» походить від англійського слова «interact». «Inter»- це взаємний, «act» - діяти. Інтерактивний - здатний взаємодіяти або перебувати в 
режимі бесіди, діалогу з будь-чим (наприклад, комп'ютером) або 3 будь-ким (людиною). Сутність інтерактивного навчання полягає в активному залученні всіх учнів допроцесу пізнання.

У педагогічній літературі описано чимало типів організації навчання (за рівнем активності учнів, рівнем залучення їх до продуктивної діяльності, за дидактичною метою, за способами організації тощо). Е.Голант (60-ті рр.) поділив типи та методи навчання на активні та пасивні залежно від участі учнів у навчальній діяльності. Звісно, термін «пасивне»є умовним, адже будь-яка організація навчального процесу неодмінно передбачає певний рівень пізнавальної активності суб'єкта - учня, інакше досягнення навіть мінімального результату неможливе. У своїй класифікації Е.Голант використовує «пасивність» як визначення низького рівня активності учнів, переважно репродуктивної діяльності за майже цілковитої відсутності самостійності й творчості. До цієї класифікації ми додамо інтерактивне навчання як різновид активного, котрий, однак, має свої закономірності та особливості.

Сутність інтерактивного навчання полягає в тому, що навчальний процес відбувається за умов постійної, активної взаємодії всіх учнів. Це співнавчання, взаємонавчання (колективне, групове, навчання в співпраці), де учень і вчитель $\epsilon$ рівноправними, рівнозначними суб'єктами навчання. Педагог виступає в ролі організатора процесу навчання, лідера групи. Організація інтерактивного навчання передбачає моделювання життєвих ситуацій, використання рольових ігор, спільне розв'язання проблем. Воно ефективно сприяє формуванню цінностей, навичок $\mathrm{i}$ вмінь, створенню атмосфери співпраці, взаємодії, дає змогу педагогу стати справжнім лідером учнівського колективу (Комар, 2006, с.57).

Сама назва «інтерактивні» технології навчання зумовлює їх віднесення до активної моделі навчання. Активна модель навчання передбачає активність учнів, при відносній пасивності навчального оточення. викладач стимулює пізнавальну діяльність, ініціативність, самостійність студентів. Знання народжуються завдяки ефективної, рівної взаємодії, співпраці всіх учасників освітнього процесу (Архипова, 2002). За рівнем застосування інтерактивні технології навчання є загально педагогічні та особистісно-орієнтованими, тобто характеризують освітній процес як процес, орієнтований на розвиток особистості кожної дитини, 3 урахуванням суб'єктного досвіду життєдіяльності кожної людини. За філософською основою прагматичні, оскільки прихильники даної концепції вважають, що інтелектуальні якості кожної людини визначені природою, і вони унікальні, оскільки кожна людина унікальна і неповторна, і прояв інтелекту пов'язано в першу чергу з індивідуальним досвідом людини, придбаним дитиною до школи, у школі, в сім'ї, в соціокультурному оточенні. Основне завдання освіти в рамках цього вчення - у наданні допомоги людини в їі самореалізації, що досягається не шляхом формування, вироблення моральних якостей, цінностей, принципів, а розвитком і примноженням тих здібностей, які закладені у дитини від народження, зумовлюючи досягнення успіху основною, першочерговою метою життя людини. За основним фактором розвитку - психогенною. Результат розвитку при застосуванні інтерактивних технологій навчання визначається, перш за все, самою людиною, тим досвідом, яким віна придбала i набуває протягом життя, психологічними процесами самовдосконалення. Такий результат передбачений й Болонським процесом. На думку В. Поповича: «Болонський процес - це не тільки формальні принципи функціонування системи вищої освіти (як світської, так і духовної), але й створення умов для формування компетентної, адаптованої до змін особистості, здатної до цілежиттєвого навчання i постійного духовного розвитку. Це передбачає впровадження компетентнісного підходу в освіті» (Попович, 2015, с. 114). 
Професійні компетентності набуваються через формальне навчання та досвід роботи. (Нігрен, 2004, с. 151) визначає професійну компетентність як «відповідну експертизу, що дозволяє людям впоратися з однією або декількома академічними завданнями, призначеними професії щодо конкретних вимог». Професійна компетентність повинна інтерпретуватися як індивідуальну відповідь на конкретні вимоги в різних контекстах і практиках.

За підходом до людини інтерактивні технології навчання відносяться до особистісно-орієнтованих технологій, засновані на педагогіці співробітництва. У цих технологіях панують суб'єкт-суб'єктні відносини між викладачем та студентами, в центрі освітнього процесу знаходиться особистість, іiі розвиток. Розвиток особистості полягає в розкритті природних здібностей кожної людини 3 опорою на його життєвий досвід. Процес навчання протікає в комфортної, безконфліктної обстановці. Педагогіка співпраці передбачає демократизм, партнерство, рівноправність, паритетність у відносинах. В освітньому процесі панує атмосфера співпраці, співтворчості. За переважаючим методом інтерактивні технології навчання характеризуються як розвиваючі, саморозвиваючі, діалогічні, комунікативні, ігрові, творчі. О.Пометун і Л.Пироженко запропонували класифікацію інтерактивних технологій навчання в залежності від форм (моделей) навчання, в яких реалізуються інтерактивні технології (Нойфельд, 1993, с.87).

Таким чином, залежно від мети заняття та форм організації навчальної діяльності дітей в інтерактивні технології навчання були ними об'єднані в чотири групи: 1) інтерактивні технології кооперативного навчання; 2) інтерактивні технології колективно-групового навчання; 3) інтерактивні технології ситуативного моделювання; 4) інтерактивні технології відпрацювання дискусійних питань.

До інтерактивних технологій кооперативного (колективного) навчання віднесені технології: «Робота в парах», «Ротаційні трійки», «Два - чотири - всі разом», «Карусель», «Робота в малих групах», «Діалог», «Синтез думок», «Спільний проект», «Пошук інформації», «Коло ідей», «Акваріум» і т. д. Застосування інтерактивних технологій кооперативного навчання сприяє об'єднанню тих, хто навчається, при прагненні рішення загальної задачі. Кожен студент за такої форми організації освітнього процесу розуміє, що досягнення кінцевого позитивного результату за даним завданням можливо при спільних діях усіх членів колективу. У даному випадку освітня мета не може бути досягнута шляхом конкуренції, суперництва. Мета є спільною для всіх, і прийти до неї можливо тільки спільно, в процесі співтворчості, співпраці. При такій формі організації занять учасники освітнього процесу відчувають свою психологічну безпеку, оскільки є присутнім інтелектуальне сприйняття всіх тих, хто навчається. Учасники процесу навчаються грамотно висловлювати свої думки, сприймати інформацію, адекватно реагувати на неї, приводити аргументи, контраргументи, вчаться вести діалог, дискусії.

До інтерактивних технологій колективно-групового навчання віднесені технології: «Обговорення проблеми у загальному колі», «Мікрофон», «Незакінчені пропозиції», «Мозковий штурм», «Навчаючись - учусь», «Мозаїка», «Аналіз ситуаціï» (Case-study ), «Вирішення проблем», «Дерево рішень» і т.д. Використання технологій колективно-групового навчання передбачають фронтальну, спільну роботу всієї аудиторії 3 вирішення певної проблеми. Завдання викладача активізація студентів в пошуку вирішення проблеми. Кожен, хто навчається, висловлює думки, свою позицію, не боячись осуду, неприйняття його точки зору. Проблема може мати і декілька способів вирішення, кількість висунутих пропозицій щодо вирішення проблеми в кінцевому підсумку обов'язково призведе 
до іï якісного вирішення і досягненню мети навчання. Технології «Навчаючись учусь», «Мозаїка» передбачають об'єднання студентів у групи, і застосовуються тоді, коли необхідно за короткий проміжок часу оволодіти великим обсягом інформації. Робота в навчальній групі сприяє формуванню комунікативних навичок, подоланню психологічних бар'єрів. Технологія «Аналіз ситуації» (casestudy - англ. мова, Fallstudie - нім. мова.) має на увазі аналіз конкретних практичних ситуацій, тобто ситуацій, які відображають реальні події, що відбувалися в минулому або відбуваються в даний момент. Також можливо, застосування штучно сконструйованих ситуацій, але таких, які гіпотетично могли б відбутися в дійсності. Завдяки використанню цієї технології, діти не лише здобувають знання, а вчаться аналізувати ситуацію, виявляти головні і другорядні моменти, оцінювати іiі, передбачати різні варіанти розвитку подій, вибирати оптимальне рішення 3 декількох, вчаться діяти, набувають практичний досвід особистісної поведінки в різних ситуаціях, досвід вірного емоційного реагування на проблему, вчаться активно і адекватно реагувати на обставини, що склалися. Застосування даної технології сприяє розвитку аналітичного мислення, формуванню оціночних умінь, розвитку комунікативних навичок, формуванню толерантного ставлення в колективі один до одного, до різних думок, поглядів, сприяє формуванню самостійності, рішучості, відповідальності як якостей особистості. У майбутніх фахівців формуються необхідні вміння, навички професійної діяльності (Павелків, 2013, с.140).

Дія case-study на формування професійних компетенцій соціальних працівників в даний час потребує додаткових досліджень. Суть освітньої технології case-study полягає в тому, що на занятті студентам пропонується осмислити реальну життєву ситуацію (зафіксовану певним чином у вигляді кейса), що не тільки відображає в своєму описі проблему, але і актуалізує певний досвід і комплекс знань, які необхідно засвоїти або застосувати при вирішенні даної проблеми. Під кейсом в даному випадку розуміється опис конкретної ситуації, яка була в професійній практиці і містить в собі деяку проблему, що вимагає дозволи. Це свого роду інструмент, за допомогою якого в учбову аудиторію привноситься частина реального життя, реальна ситуація, над якою належить попрацювати i представити обгрунтоване рішення (Баев, 2008, с.12). При цьому якщо говорити про застосування технологіï case-study в системі професійної підготовки соціальних працівників, то кейси повинні відповідати деяким специфічним вимогам, а саме: 1) кейс повинен відображати проблемну ситуацію, пов'язану з об'єктом соціальної роботи (з певною категорією клієнтів: безробітними, неблагополучними сім'ями, важкими підлітками, інвалідами, немолодими, правопорушниками і т. п.); 2) проблемна ситуація, описана в кейсі, повинна мати на увазі застосування знань технологій, методів, форм соціальної роботи 3 даною категорією клієнтів; 3) кейс повинен давати можливість при рішенні проблеми спиратися на знання нормативно-правової бази, що регламентує соціальну роботу з певною категорією населення; 4) бажано, щоб кейс мав декілька варіантів рішення.

До інтерактивних технологій ситуативного моделювання відносять симуляції та імітаційні ігри: «Судове слухання», «Громадське слухання», розігрування ситуацій за ролями: «Рольова гра», «Відтворення сценки», «Драматизація» і т.д. Застосування ігор в освітньому процесі сприяє активізації учнів у процесі пізнання, розвитку пізнавального інтересу до матеріалу, що вивчається, оволодіння знаннями, вміннями та навичками 3 дисциплін. Застосування ігор сприяе створенню позитивної психологічної атмосфери в колективі. У грі закладені величезні виховні можливості, використання ігор сприяє формуванню навичок міжособистісного спілкування, 
розвитку комунікативних здібностей, виробленню навичок роботи в малих групах, формуванню умінь самостійного мислення, формуванню терпимого відношення до слів, думок, дій інших, студенти отримують практичний досвід діяльності у різних ситуаціях і т.д. Зараз набуває поширення поняття «симуляція» або «імітація». В імітаційних іграх спостерігається копіювання, відтворення, імітація явищ навколишньої дійсності, подій, що представлені у вигляді певних дій. Симуляції є більш складними іграми, що представляють собою в спрощеному варіанті діяльність громадських, соціальних інститутів. Також зустрічається поняття «ділова гра», яка передбачає розподіл ролей між учасниками гри та виконання ними певних ролей, 3 відображенням функціональних прав i обов'язків кожного представника ігрової групи, як би ділові стосунки складалися в реальних умовах. Ділові ігри відрізняються тим, що в їхньому сюжеті зазвичай стикаються різні інтереси сторін з обов'язковим находженням компромісу, оптимального рішення після закінчення гри. Застосування інтерактивних технологій ситуативного моделювання вимагає від викладача попередньої чіткої, ретельної підготовки, оскільки він встановлює цільову необхідність застосування тісї чи іншої гри в навчальному процесі, тобто необхідно чітко продумати, з якою метою буде використана гра, визначити освітні, виховні, розвиваючі цілі і кінцеві результати іï застосування. Важливим моментом є вміння зацікавити студентів майбутньою ігровою діяльністю, спонукати їх до виконання ролей. Соціальному працівникові треба продумати, яким способом студенти будуть введені в тему, в ситуацію, яким чином буде підкріплюватися їх мотиваційний стан, які будуть правила гри, або визначені ролі. Важливим є вміння спрогнозувати хід розвитку гри, визначити зміст навчального матеріалу, те, яким чином при необхідності буде поповнюватися відсутня інформація, яка необхідна для вирішення проблеми. Як буде проведено заключне обговорення результатів гри з виходом на придбаний досвід, почуття, які ними опановували в момент виконання ролі.

Інтерактивна педагогічна взаємодія характеризується високим рівнем інтенсивності спілкування іiі учасників, їх комунікації, обміну діяльностями, зміною та різноманіттям їх видів, форм i прийомів, цілеспрямованою рефлексією учасниками своєї діяльності та взаємодії, що відбулася. Інтерактивні форми навчання допомагають зробити кожного не лише слухачем чи спостерігачем, а й активним учасником навчального процесу. Психологічною сутністю інтерактивного навчання $\epsilon$ міжособистісна взаємодія у процесі спілкування і співпраці між учасниками освітнього процесу (Александрова, 2002).

Використовуючи інтерактивні технології у процесі підготовки, доцільно враховувати провідну функцію цих інновацій у педагогічній взаємодії. За цим критерієм інтеракції класифікуються на такі групи методів: створення сприятливої атмосфери, організації комунікації; організації обміну діяльностями; організації миследіяльності; організації смислотворчості; організації рефлексивної діяльності; інтегративні (інтерактивні ігри) (Архипова, 2002, с.23). Використання методів організації обміну діяльностями має на меті поєднання індивідуальної та групової спільної роботи учасників педагогічної взаємодії, спільну активність, співвідношення діяльності викладача і студентів (Богданов, 2002, с.58).

Іншою сучасною формою інтерактивного навчання в системі професійної підготовки соціальних працівників є навчальний тренінг. Навчальний тренінг це форма активного навчання, спрямована на оволодіння учасниками певними знаннями, технологіями, навичками та інформацісю; під час навчання майбутні фахівці виконують тренінгові вправи адаптовані до майбутньої професійної діяльності під керівництвом викладача-тренера на основі спеціально підготовлених 
інструктивно-методичних матеріалів відповідних сучасним вимогам до професійної діяльності.

Тренінги дають змогу реалізувати потребу майбутніх фахівців у спілкуванні, груповій взаємодії, прямому й опосередкованому впливі на інших людей. Особливої актуальності у контексті досліджуваної проблеми набуває наукова позиція Т.Гери. Науковець твердить, що ідеєю організації професійно зорієнтованого тренінгу є використання тренінгової групи не лише для навчання, але й психотерапевтичної роботи з кожним учасником на основі групової динаміки (Гера, 2012, с.267).

Сьогодні наявна велика кількість модифікацій конкретних форм тренінгів, відповідно до якої тренінг - це: а) своєрідна форма дресури, коли за допомогою жорстких маніпулятивних прийомів формуються зміни в поведінці, «стираються» шкідливі, на думку керівника тренінгу, звички; б) тренування, в результаті якого відбувається формування та відпрацювання вмінь і навичок ефективної поведінки; в) форма інтерактивного навчання, метою якого $\epsilon$ передача знань, а також розвиток певних умінь і навичок; г) метод створення умов для саморозкриття учасників $\mathrm{i}$ самостійного пошуку способів розв'язання власних психологічних проблем.

Мета тренінгової групи - формування навичок міжособистісного спілкування 3 різними категоріями населення, реалізація творчого потенціалу, розвиток здатності до самопізнання. Зміст тренінгів має бути спрямований на вироблення навичок у майбутніх соціальних працівників вступати у взаємодію 3 об'єктами соціальнопедагогічної діяльності, тактовно і цілеспрямовано вести з ними бесіду, ураховувати інтереси й потреби клієнта, розуміти мотиви вчинків і поведінки клієнтів, знаходити до них індивідуальний підхід, прогнозувати їхній розвиток, результати роботи та післядію.

Під час тренінгу відбувається неформальне, невимушене спілкування, яке відкриває перед групою варіанти розвитку й розв'язання соціальних проблем. Навчальний тренінг і традиційні форми навчання мають суттєві відмінності. Традиційне навчання більш орієнтоване на правильну відповідь і за своєю сутністю $є$ формою передачі інформації та засвоєння знань. Натомість навчальний тренінг передовсім орієнтований на запитання та пошук. На відміну від традиційних, тренінгові форми навчання повністю охоплюють весь потенціал людини: рівень та обсяг ії компетентності (соціальної, емоційної та інтелектуальної), самостійність, здатність до прийняття рішень, до взаємодії тощо. Звичайно, традиційна форма передачі знань не є сама по собі чимось негативним, проте у світі швидких змін традиційна форма навчання має звужені рамки застосування.

Проведення тренінгів передбачає інформування про певні соціальнопедагогічні явища; здобуття учасниками професійно значущих знань та умінь; формування навичок співпраці і толерантного ставлення; формування навичок комунікативної взаємодії; презентації та відстоювання власної соціальнопедагогічної позиції; формування вмінь адекватно оцінювати власні можливості, переборювати труднощі і шукати шляхи самовдосконалення та конструктивного розв'язання проблемних і конфліктних ситуацій; виховання емоційної культури.

На відміну від традиційних методів навчання, ігрові методи мають чимало переваг, що характеризують їх як методи активного й інтерактивного навчання. Поперше, професійні стосунки, що моделюються в ігрових технологіях, забезпечують включеність студентів до імітованого середовища професійно-комунікативної діяльності фахівців соціальної роботи. Як об'єкти професійно-комунікативних взаємин, учасники гри набувають необхідних навичок i вмінь налагоджувати комунікативну взаємодію із клієнтами, виконувати професійні обов'язки, що сприяє інтенсивному формуванню їх професійно-комунікативної компетентності. По-друге, 
емоційно-творчий пошуковий характер діяльності учасників гри є дидактичним засобом розвитку творчого (теоретичного і практичного) професійного мислення, розвиває уміння ефективно взаємодіяти з партнером. По-третє, ділова гра розкриває особистісний потенціал майбутніх фахівців. Кожен учасник групи може оцінити власні можливості як індивідуально, так і в колективній діяльності 3 іншими учасниками. Застосування ігрових методів дає змогу діагностувати не тільки професійно-комунікативні якості учасників, а й типовий розвиток окремих професійних ситуацій. У сучасній педагогічній літературі гра кваліфікується і як цілісна самодостатня технологія, і як відносно закінчена ії частина - методика, і як елемент методики - ігровий прийом, що легко включається у будь-яку іншу технологію (практикум, заліки тощо) (Стрельніков, 2002, с. 156). Крім того, ділові і рольові ігри можуть легко інтегруватися із іншими інноваційними технологіями навчання. Так, ігри можуть включати елементи тренінгу, розгляд конкретних ситуацій, дискусію, що визначається загальною метою їх застосування. 3 іншого боку, ігрові методи навчання можуть бути складовими тренінгу і методу кейсів, або аналізу проблемних ситуацій. На нашу думку, ефективними для формування комунікативної компетенції майбутніх фахівців соціальної роботи є ділові і рольові ігри у їх комплексному поєднанні, що забезпечують моделювання професійнокомунікативної діяльності майбутніх соціальних працівників і способів їх взаємодії 3 клієнтами у різних комунікативних ситуаціях. Аналіз психолого-педагогічних досліджень із проблематики застосування ігрових технологій навчання показує, що відмінності ділової та рольової гри є розмитими, оскільки ділові ігри, у яких наголошується на рольовому виконанні, часто називаються рольовими. Головною відмінністю ділової гри від рольової $\epsilon$ іï орієнтація на майбутню професійнокомунікативну діяльність фахівців соціальної роботи, моделювання у грі умов професійно-комунікативної діяльності, наближених до реальних. Крім того, в основі ділової гри може бути не лише проблемна, але й конфліктна ситуація, вирішити яку мають всі учасники спілкування разом, а сама гра має поетапний розвиток, в результаті якого виконання завдань попереднього етапу впливає на хід наступного, на контроль ігрового часу і систему оцінки їі результатів. На противагу діловим іграм, рольові ігри мають сценарій, у який закладено жорсткий алгоритм «правильності» і «хибності» ухвалюваного рішення, тобто учасник ігрової взаємодії у змозі бачити вплив, який справляє його поведінка на майбутні події і ставлення до нього інших гравців.

\section{Висновки}

Таким чином, інтерактивні технології (case-study, навчальний тренінг, рольові $i$ ділові ігри є способами соціально-педагогічної взаємодії викладача та студента (майбутнього соціального працівника), у яких інтегруються всі провідні функції інтерактивних методів навчання. Саме змодельовані ігрові ситуації можуть бути прототипом майбутніх життєвих ситуацій , що надає змогу шляхом активної участі в таких інтеракціях спробувати свої дії до вирішення складної життєвої ситуації, в яку потрапив клієнт.

\section{Література}

Александрова, О. Н. (2002). Психология сочиальной работы : учеб. для вузов. Санктпетербург: Питер, 350.

Архипова, С. П. (2002). Соціальна педагогіка. Чернівці: Джерело, 154.

Баев, П.А. (2008).Практикум по методике Case-study: учебное пособие. Иркутск : РИО НЦ РВХ ВСНЦ СО РАМН, 210. 
Біда, О. С. (2007). Структура і методика інтерактивного уроку. Початкова школа, по.7, 23-29.

Богданов, С. В. (2002). Соччіальний захист інвалідів. Київ: Вид-во Соломії Павличко «Основи», 93.

Гера, Т. I. (2012). Психотерапевтичні засади організації професійно зорієнтованого тренінгу майбутніх інженерів-педагогів. Інноваційні підходи до науки XXI столітті: зб. наук. праць і матеріалів міжнарод. наук.-практ. конф. (27 квітня 2012 року) / гол. ред. В.С. Рижиков. Кіровоград : Науково-дослідний центр інноваційних технологій, 267-270.

Гриненко, А. М. (2003). Соціальна політика: Навч.-метод. посібник для самостійного вивчення дисципліни. Київ: КНЕУ, 134.

Комар, О. В. (2006). Навчання школярів за інтерактивними методами. Рідна школа, по.5, 57-60.

Нойфельд, И. (1993). Методы социальной работы. Теория и практика сочиальной работы: отечественный и зарубежный опыт. Тула, 322-343.

Павелків, Р.В. (2013). Загальна психологія : підручник для студ. вищ. навч. закл. Київ: Кондор, 576.

Попович, В. М. (2015). Компетентнісний підхід у Православній богословській освіті в контексті іiі модернізації. Грані: науково-теоретичний альманах, №4 (122), 112-117.

Стрельніков, В. Ю. (2002). Педагогічні основи особистісного й професійного розвитку студентів засобами інновачійних технологій навчання. Полтава : РВВ ПУСКУ, 230.

Гус, Е., Села-Аміт, М. (2018). Искусство в социальной работе: действительно ли оно нам нужно? Исследование практики социальной работы. https://doi.org/10.1177/1049731517745995

Нигрен П. (2004). Експертиза професіоналів. Осло, Гюльдендаль, Академік. 


\title{
FEATURES OF INTERACTIVE TRAINING TECHNOLOGIES IN SOCIAL WORKERS PROFESSIONAL TRAINING
}

\author{
Vitaliy Dudaryov, PhD in Political Sciences, Associate Professor of Social \\ Work Department, National University "Zaporizhzhya Polytechnic", \\ Zaporozhye,Ukraine, kafedra_sr@zntu.edu.ua
}

\begin{abstract}
Sergii Shcherbina, PhD in Social Sciences, Associate Professor of Social Work Department, National University "Zaporizhzhya Polytechnic", Zaporozhye, Ukraine, sergshcherbina70@gmail.com
\end{abstract}

\begin{abstract}
The article discusses the interactive learning essence, which lies in the fact that the learning process in a permanent, active interaction of all students. This co-educational, mutual learning (collective, group, learning in cooperation) were the student and teacher were equal, equivalent learning subjects. The teacher acts as the learning process organizer, the group leader. The interactive learning organization involves the life situations modeling, the role-playing games use, and the general solution of problems. It effectively contributes to the values formation, skills and ability, creating a cooperation and interaction atmosphere, allows the teacher to become a true leader in the student team. The structural and procedural interactive technologies characteristics are considered.

It is analyzed that the active learning model implies the students' activity, with relative learning environment passivity. The teacher stimulates cognitive activity, initiative and independence. The main task of education within the framework of this doctrine is to assist a person in his self-realization, which is achieved not through the formation, moral qualities, values, principles development, but the development and enhancement of those abilities that are born into a child from birth, causing the success achievement as the main, primary human life purpose. From the orientation towards personal structures, interactive learning technologies are information-operational, since they contribute to the knowledge and skills formation in subjects, as well as methods of mental actions.
\end{abstract}

Keywords: training; interactive technologies; social worker; training model.

\section{References}

Aleksandrova, O. N. (2002). Psikhologiia sotcialnoi raboty (Psychology of social work) : ucheb. dlia vuzov. Sanktpeterburg: Piter, 350. [in Ukrainian].

Arkhypova, S. P. (2002). Socialjna pedaghoghika (Social pedagogy). Chernivci: Dzherelo, 154. [in Ukrainian].

Baev, P. A. (2008). Praktikum po metodike Case-study: uchebnoe posobie. Irkutsk : RIO NTc RVKh VSNTc SO RAMN, 210. [in Ukrainian].

Bida, O. S. (2007). Struktura i metodyka interaktyvnogho uroku (Structure and methodology of the interactive lesson). Pochatkova shkola, no.7, 23-29. [in Ukrainian].

Boghdanov, S. V. (2002). Socialjnyj zakhyst invalidiv (Social protection of the disabled). Kyjiv: Vyd-vo Solomiji Pavlychko «Osnovy», 93. [in Ukrainian].

Huss, E. \& Sela-Amit, M. (2018). Art in social work: do we really need it? Research on social work practices . https://doi.org/10.1177/1049731517745995.

Ghera, T. I. (2012). Psykhoterapevtychni zasady orghanizaciji profesijno zorijentovanogho treninghu majbutnikh inzheneriv-pedaghoghiv. Innovacijni pidkhody 
do nauky KhKhI stolitti: zb. nauk. pracj i materialiv mizhnarod. nauk.-prakt. konf. (27 kvitnja 2012 roku) / ghol. red. V.S. Ryzhykov. Kirovoghrad : Naukovo-doslidnyj centr innovacijnykh tekhnologhij, 267-270. [in Ukrainian].

Ghrynenko, A. M. (2003). Socialjna polityka (Social policy): Navch.-metod. posibnyk dlja samostijnogho vyvchennja dyscypliny. Kyjiv: KNEU, 134. [in Ukrainian].

Komar, O. V. (2006). Navchannja shkoljariv za interaktyvnymy metodamy (Teaching students through interactive methods). Ridna shkola, no.5, 57-60. [in Ukrainian].

Noifeld, I. (1993). Metody sotcialnoi raboty (Social work methods). Teoriia $i$ praktika sotcialnoi raboty: otechestvennyi $i$ zarubezhnyi opyt. Tula, 322-343. [in Ukrainian].

Nygren P. (2004) Handlingskompetanse: Om profesionelle personer [Competence to Act: About Professionals], Oslo, Gyldendal Akademisk, 151.

Pavelkiv, R. V.(2013). Zaghaljna psykhologhija (General Psychology): pidruchnyk dlja stud. vyshh. navch. zakl. Kyjiv: Kondor, 576. [in Ukrainian].

Popovych, V. M. (2015). Kompetentnisnyj pidkhid u Pravoslavnij boghoslovsjkij osviti v konteksti jiji modernizaciji. Ghrani: naukovo-teoretychnyj aljmanakh, no.4 (122), 112-117. [in Ukrainian].

Streljnikov, V. Ju.(2002). Pedaghoghichni osnovy osobystisnogho j profesijnogho rozvytku studentiv zasobamy innovacijnykh tekhnologhij navchannja. Poltava : RVV PUSKU, 230. [in Ukrainian].

Nygren P. (2004) Handlingskompetanse: Om profesionelle personer [Competence to Act: About Professionals], Oslo, Gyldendal Akademisk. 
